\title{
BIOCHEMICAL, PHYSIOLOGICAL AND GROWTH CHANGES IN RESPONSE TO IN VITRO SALINITY IN SUGARCANE
}

\author{
ALTERAÇÕES BIOQUÍMICAS, FISIOLÓGICAS E DE CRESCIMENTO EM \\ RESPOSTA À SALINIDADE IN VITRO EM CANA-DE-AÇÚCAR
}

\section{Leila Albuquerque Resende de OLIVEIRA ${ }^{1}$; Milena Nascimento CARDOSO ${ }^{1}$; Annie Carolina Araújo de OLIVEIRA ${ }^{\mathbf{1}}$; Caroline de Araújo MACHADO²} Fernanda Vieira SANTANA ${ }^{3}$; Bruno Trindade CARDOSO ${ }^{4}$; Evaristo Mauro de CASTRO ${ }^{5}$; Ana Veruska Cruz da SILVA ${ }^{6}$; Ana da Silva LEDO ${ }^{6}$

1. PhD student in Agricultura e Biodiversidade, Universidade Federal de Sergipe, São Cristóvão, SE, Brazil. leila.a.resende@ gmail.com; 2. PhD in Agricultura e Biodiversidade, Universidade Federal de Sergipe, São Cristóvão, SE, Brazil; 3. Master in Agricultura e Biodiversidade, Universidade Federal de Sergipe, São Cristóvão, SE, Brazil; 4. Analyst at the Embrapa Tabuleiros Costeiros, Aracaju, SE, Brazil; 5. Professor in the Universidade Federal de Lavras, Lavras, MG, Brazil; 6. Research at the Embrapa Tabuleiros Costeiros, Aracaju, SE, Brazil.

\begin{abstract}
Abiotic stresses in plants have aroused great research interest, unceasingly seeking for more productive cultivars under unfavorable cultivation conditions. Water deficiency and soil salinity are the most studied aspects, due to their strong impact on the growth and productivity of plants. The objective of this study was to evaluate accessions of different sugarcane species (Saccharum spp., S. robustum, S. officinarum) regarding tolerance to in vitro salinity, from changes in physiological, anatomical, biochemical and biometric parameters, to assist in breeding programs. To this end, shoots were used, grown on Murashige and Skoog medium, supplemented with $2 \%$ of sucrose and 4 g. $\mathrm{L}^{-1}$ Phytagel, in the presence of five concentrations 0, 50, 100, 150, $200 \mathrm{mM} \mathrm{NaCl}$. Shoots length, roots length, shoots number, roots number, fresh weight, dry weight, proline content in leaves, total chlorophyll content, and morphological changes to the leaf tissue were analyzed. The in vitro growth of accessions Saccharum robustum, Saccharum spp. and Saccharum officinarum are affected by salinity induced by $\mathrm{NaCl}$. The proline accumulation and chlorophyll decrease are intensified in Saccharum spp., in addition to changes in cell's anatomy, characterized as more sensitive to salt.
\end{abstract}

KEYWORDS: Chlorophyll. Histology. Proline. Saccharum officinarum. Saccharum robustum. Saccharum spp.

\section{INTRODUCTION}

Sugarcane (Saccharum sp.) is a plant of the Poaceae family, of $\mathrm{C}_{4}$ photosynthetic metabolism, native to Southeast Asia (CASU et al., 2004), that is quite sensitive to salinity (AKHTAR et al, 2003; PLAUT et al., 2000). Wahid and Ghazanfar (2006) state that salt tolerance varies among sugarcane varieties.

The plants response to salinity conditions is related to degree of salt tolerance, which depends on concentration and nature of dissolved salts, climatic factors, water absorption, and plant nutrition (VASANTHA; GOMATHI, 2012). The different responses obtained from varieties of sugarcane regarding tolerance to salinity are related to the mechanisms developed by them to minimize the osmotic effect of salts in the soil, which limits the water absorption besides the less vulnerability to toxic concentrations of ions such as $\mathrm{Na}^{+}$and $\mathrm{Cl}^{-}$ (MUNNS; TESTER, 2008).

Generally, the first effect of salinity on plants development is growth reduction, caused by water potential decrease in soil solution to a level below the necessary for the water absorption by root cells, thus preventing cell expansion, since the potential of cell pressure tends to equate with that of the soil (TAIZ; ZEIGER, 2009).

Several protection mechanisms are activated in plants due to adverse growth conditions, among them osmotic adjustment through the compatible solutes accumulation, becoming one of the most effective physiological mechanisms to protect and maintain the cell's turgescence (MARIJUAN; BOSCH, 2013).

Some other physiological and biochemical strategies to tolerate salt stress damage include selective ion accumulation or exclusion, changes in photosynthetic pathways, photosynthetic pigment degradation, decreased of stomatal conductance, changes in membrane structures, induction of hormones and enzymes antioxidants (ASHRAF; HARRIS, 2004; MUDGAL et al. 2010; NAWAZ et al. 2010; PARIDA; DAS, 2005). These aspects have already been studied in banana (WILLADINO et al., 2017), potato (TEIXEIRA; PEREIRA, 2007), rice (REDDY et al., 2017; CHA-UM et al., 2007), maize (HU et al., 2007), and in in vitro sugarcane crops under stress (AVINASH et al., 2012; CHA-UM; KIRDMANEE, 2009; ERRABII et al., 2007; 
PATADE et al., 2012; PATADE et al., 2008; POONSAWAT et al., 2015). However, more detailed studies of these changes caused by stresses, associated with observation of the cells at the anatomical level are still scarce.

In addition to being characterized as a serious environmental problem, the high concentration of salts in the soil causes considerable losses for world agriculture, either in established crops or by making the exploitation of new arable areas unfeasible (MUNNS et al., 2006). Thus, the abiotic stresses in plants have aroused great research interest, unceasingly seeking for more productive cultivars under unfavorable cultivation conditions (FILIPPOU et al., 2014).

In vitro crop, in addition to providing study techniques in a controlled environment, reduces the initial cost of research, thus being an alternative to speed up the process of selecting genotypes tolerant to such conditions (ANDRADE, 2002). Given this, the objetive of this study was to evaluate accessions of different sugarcane species (Saccharum spp., $S$. robustum, $S$. officinarum) regarding tolerance to in vitro salinity, from changes in physiological, anatomical, biochemical and biometric parameters, to assist in breeding programs.

\section{MATERIAL AND METHODS}

The experiments were conducted at the Plant Tissue Culture Laboratory, the Plant Ecophysiology Laboratory of Embrapa Tabuleiros Costeiros, in Aracaju, Sergipe, Brazil, and Plant Anatomy Laboratory of the Universidade Federal de Lavras, Minas Gerais, Brazil.

\section{Plant material}

As plant material, shoots were used from accessions: Q44830 - Saccharum officinarum; Q45251 - Saccharum robustum; Q45416 Saccharum spp., previously established in vitro, from Queensland (Australia), provided by the National Center for Genetic Resources Preservation/ARS/USDA, Fort Collins, CO, USA, which are part of Sugarcane Active Germoplasm Bank of Embrapa Tabuleiros Costeiros, Aracaju, Sergipe, Brazil.

\section{Growing conditions and stress treatment}

Every 30 days, crops were multiplied in aseptic environment, in test tubes containing $20 \mathrm{~mL}$ of the multiplication medium (MM) consisting of salts from the MS (MURASHIGE; SKOOG, 1962), supplemented with $2 \%$ sucrose, $0.2 \mathrm{mg} . \mathrm{L}^{-1}$ BAP (6- benzylaminopurine) $+0.1 \mathrm{mg} \cdot \mathrm{L}^{-1}$ kinetin, gelified with 4 g.. $\mathrm{L}^{-1}$ Phytagel, and $\mathrm{pH}$ adjusted to 5.8 .

The medium was autoclaved at $121^{\circ} \mathrm{C}$ for 20 minutes. The crops were maintained under conditions of $\left(25 \pm 2^{\circ} \mathrm{C}\right)$ ambient temperature, photoperiod of 16 hours under luminous intensity 60 $\mu \mathrm{molm} \mathrm{s}^{-1}$.

After three subcultivations, shoots with approximately $3 \mathrm{~cm}$ long were transferred to test tubes with $20 \mathrm{~mL}$ of culture medium with MS medium, supplemented with $2 \%$ sucrose, and gelified with $4 \mathrm{~g} . \mathrm{L}^{-1}$ Phytagel, in the presence of five $\mathrm{NaCl}$ concentrations: $0,50,100,150$, and $200 \mathrm{mM}$.

The tubes were sealed with polyethylene plastic film and the crops were transferred to the growth room under the same conditions previously described.

\section{Biometric, physiological, and biochemical characters Growth assessment}

After 60 days the variables length of shoots and roots $(\mathrm{cm})$, fresh $(\mathrm{FW})$ and dry (DW) weight, number of shoots and roots were evaluated according to Oliveira et al. (2018a).

\section{Determining the Proline content}

The proline content of leaves was determined at 20, 40, and 60 days according to the method by Bates et al. (1973): a gram of leaf tissue was macerated in a mortar with $10 \mathrm{~mL}$ of 5 sulfosalicylic acid solution at $3 \%$. The macerated leaves were transferred to tubes and centrifuged at $5.000 \mathrm{rpm}$ for 20 minutes. $1 \mathrm{~mL}$ of the supernatant solution was made to react with an equal volume of glacial acetic acid and Ninhydrin reagent $(1.25 \mathrm{mg}$ Ninhydrin in $30 \mathrm{~mL}$ of glacial acetic acid and $20 \mathrm{~mL}$ of $\mathrm{H}_{3} \mathrm{PO}_{4}$ at $6 \mathrm{M}$ ) and incubation at $100^{\circ} \mathrm{C}$ for $1 \mathrm{~h}$. The reaction was terminated by placing it in an ice bath. The reaction mixture was mixed with $2 \mathrm{~mL}$ of toluene, shaken and set aside until phases separation. The reading the colorful phase was conducted in a $520 \mathrm{~nm}$ spectrophotometer, using Lproline as default, and toluene as white.

\section{Estimate of Chlorophyll content}

The total chlorophyll content was quantified at 20,40, and 60 days, according to the method by Arnon (1949): $100 \mathrm{mg}$ of leaves were macerated in a mortar with a small amount of magnesium carbonate in the absence of light, and after the formation of a paste, $10 \mathrm{~mL}$ of acetone at $80 \%$ was added. The macerated leaves were transferred to bottles wrapped with aluminum foil, and later centrifuged at $8,000 \mathrm{rpm}$ for 20 minutes at a 
temperature of $4^{\circ} \mathrm{C}$. The concentration of chlorophyll $a$ and $b$ were measured using a spectrophotometer with visible $\mathrm{UV}$ at $645 \mathrm{~nm}$ and $663 \mathrm{~nm}$. A solution of $80 \%$ of acetone was used as white.

\section{Histological analysis}

After 60 days of in vitro cultivation, leaf tissues samples from the different treatments and accessions were fixed in FAA 70\% (Formaldehyde, glacial acetic acid, 70\% ethanol) for 72 hours, dehydrated in an increasing ethylic series $(80 \%$, $90 \%$ and $100 \%$ ) at 1 hour intervals, infiltrated in infiltration solution (Leica Microsystems kit, Heidelberg, Germany) and polymerized in histolmods. The microtomy was performed using a semi-automatic microtome (model YD335) with 8 $\mu \mathrm{m}$ thick cuts that were subsequently stained with toluidine blue $\mathrm{pH} 4.8$ and observed under an optical microscope (Nikon Eclipse E100 coupled to the Infinity 1 camera) where the photomicrographs were performed (OLIVEIRA et al., 2018b).

\section{Experimental designs and statistical analysis}

A completely randomized design was employed, using a factorial scheme 3 accessions x 5 $\mathrm{NaCl}$ concentrations with five replicate, containing one shoot with approximately $3 \mathrm{~cm}$ long per tube per experimental unit.

For comparing the proline and chlorophyll contents, the completely randomized design was used in a split-split plot in time, with the accession and $\mathrm{NaCl}$ factors was used in plot and time in subplot, with three repetitions.

Data of the variables were submitted to analysis of variance. For the $\mathrm{NaCl}$ levels, the regression analysis was used and for time and accessions, the Tukey test with 5\% of significance was used. We used the statistical software SAS-9.4 (SAS INSTITUTE, 2013) for all the analyses.

\section{RESULTS AND DISCUSSION}

\section{Effect of salinity on biometric characters}

The in vitro growth of sugarcane explants was strongly affected by the presence of $\mathrm{NaCl}$. There was significant interaction between accessions and $\mathrm{NaCl}$ concentration for: shoots length, roots length, roots number, and shoots number.

For shoots length, a linear response was observed, with significant reduction in Saccharum robustum (Q45251), Saccharum spp. (Q45416) and S. officinarum (Q44830) with the increase of $\mathrm{NaCl}$ (Figure 1A). Saccharum robustum (Q45251) was the accession that showed the highest average growth in all $\mathrm{NaCl}$ concentrations (Table 1). The inhibition of shoots elongation results from two processes: reduction of water absorption due to the water shortage caused by salinity and high ions concentration ions in transpiratory flow, causing changes in leaves (GORDIN et al., 2012; TAIZ; ZEIGER, 2009).

Table 1. Shoots length, Roots length, Roots number, and Shoots number (mean \pm standard error of the mean) of the sugarcane accessions at 60 days in vitro cultivation in different saline concentrations.

\begin{tabular}{|c|c|c|c|c|c|}
\hline \multirow{2}{*}{ Accessions } & \multicolumn{5}{|c|}{$\mathrm{NaCl}(\mathrm{mM})$} \\
\hline & 0 & 50 & 100 & 150 & 200 \\
\hline & \multicolumn{5}{|c|}{ Shoots length $(\mathrm{cm})$} \\
\hline S. robustum (Q45251) & $26.80 \pm 0.64 \mathrm{a}^{1}$ & $26.87 \pm 0.76 \mathrm{a}$ & $19.30 \pm 1.66 \mathrm{a}$ & $12.87 \pm 0.39 \mathrm{a}$ & $9.83 \pm 1.01 \mathrm{a}$ \\
\hline Saccharum spp. (Q45416) & $28.50 \pm 1.54 \mathrm{a}$ & $22.80 \pm 1.68 b$ & $8.00 \pm 0.50 \mathrm{~b}$ & $8.15 \pm 0.56 \mathrm{~b}$ & $4.90 \pm 0.82 \mathrm{~b}$ \\
\hline S. officinarum (Q44830) & $19.25 \pm 0.87 b$ & $13.70 \pm 0.73 c$ & $8.20 \pm 0.82 b$ & $6.15 \pm 0.77 b$ & $8.10 \pm 0.49 \mathrm{ab}$ \\
\hline \multirow[t]{2}{*}{ CV $(\%)$} & 14.74 & & & & \\
\hline & \multicolumn{5}{|c|}{ Roots length $(\mathrm{cm})$} \\
\hline S. robustum $(\mathrm{Q} 45251)$ & $5.47 \pm 0.31 \mathrm{~b}$ & $5.20 \pm 0.43 \mathrm{a}$ & $2.10 \pm 0.26 \mathrm{~b}$ & $1.19 \pm 0.15 b$ & $0.81 \pm 0.22 \mathrm{~b}$ \\
\hline Saccharum spp. (Q45416) & $6.05 \pm 0.12 \mathrm{ab}$ & $6.20 \pm 0.12 \mathrm{a}$ & $2.80 \pm 0.55 \mathrm{ab}$ & $3.10 \pm 0.60 \mathrm{a}$ & $0.73 \pm 0.12 b$ \\
\hline S. officinarum (Q44830) & $6.75 \pm 0.16 \mathrm{a}$ & $5.30 \pm 0.34 \mathrm{a}$ & $3.80 \pm 0.58 \mathrm{a}$ & $1.80 \pm 0.35 \mathrm{~b}$ & $2.40 \pm 0.39 \mathrm{a}$ \\
\hline \multirow[t]{2}{*}{$\mathrm{CV}(\%)$} & 22.25 & & & & \\
\hline & \multicolumn{5}{|c|}{ Roots number } \\
\hline S. robustum (Q45251) & $14.00 \pm 0.78 \mathrm{a}$ & $7.40 \pm 1.18 \mathrm{a}$ & $6.06 \pm 1.01 \mathrm{a}$ & $4.33 \pm 1.07 \mathrm{a}$ & $2.58 \pm 0.84 \mathrm{ab}$ \\
\hline Saccharum spp. (Q45416) & $12.70 \pm 1.69 \mathrm{ab}$ & $6.50 \pm 0.27 \mathrm{a}$ & $3.70 \pm 0.72 \mathrm{a}$ & $4.60 \pm 0.48 \mathrm{a}$ & $1.70 \pm 0.54 \mathrm{~b}$ \\
\hline S. officinarum (Q44830) & $10.40 \pm 1.26 \mathrm{~b}$ & $7.20 \pm 1.05 \mathrm{a}$ & $6.20 \pm 0.46 \mathrm{a}$ & $4.80 \pm 0.34 \mathrm{a}$ & $4.90 \pm 0.46 \mathrm{a}$ \\
\hline
\end{tabular}




\begin{tabular}{lccccc}
\cline { 2 - 6 } CV $(\%)$ & 15.25 \\
\hline \multicolumn{5}{c}{ Shoots number } \\
\hline S. robustum (Q45251) & $5.87 \pm 0.49 \mathrm{a}$ & $3.27 \pm 0.46 \mathrm{a}$ & $2.93 \pm 0.92 \mathrm{ab}$ & $2.87 \pm 0.25 \mathrm{a}$ & $2.90 \pm 0.73 \mathrm{a}$ \\
Saccharum spp. (Q45416) & $3.20 \pm 0.37 \mathrm{~b}$ & $3.70 \pm 0.46 \mathrm{a}$ & $3.50 \pm 0.63 \mathrm{a}$ & $2.30 \pm 0.46 \mathrm{a}$ & $1.90 \pm 0.46 \mathrm{a}$ \\
S. officinarum (Q44830) & $4.00 \pm 0.65 \mathrm{~b}$ & $1.40 \pm 0.29 \mathrm{~b}$ & $1.70 \pm 0.34 \mathrm{~b}$ & $1.90 \pm 0.46 \mathrm{a}$ & $2.60 \pm 0.33 \mathrm{a}$ \\
\hline
\end{tabular}

$\mathrm{CV}(\%)$ 16.92

${ }^{1}$ Means followed by the same letter in the column do not differ by Tukey test at $0.05 \%$ probability level.
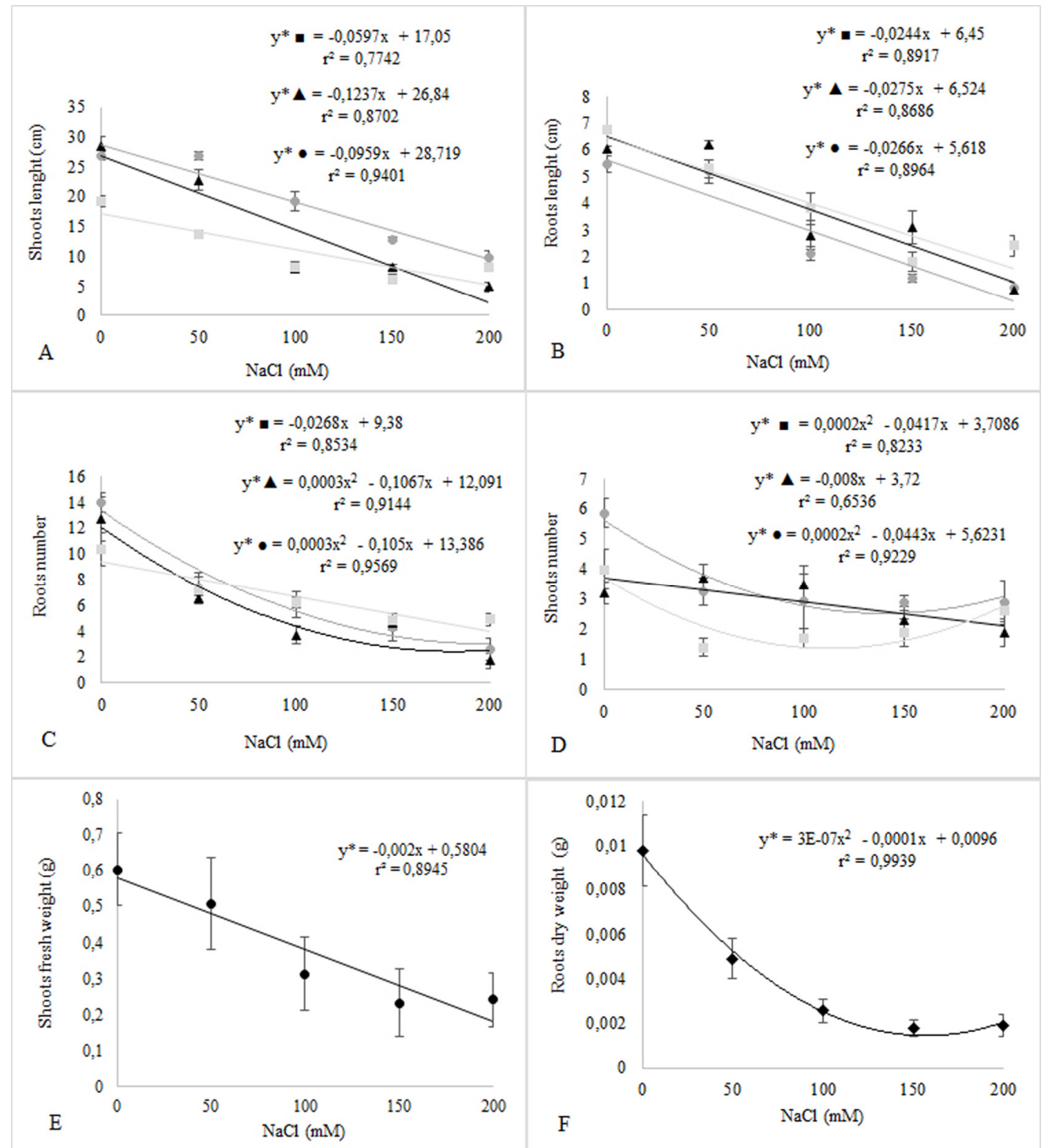

Figure 1. Effect of in vitro salinity in the shoots length $(\mathbf{A})$, roots length $(\mathbf{B})$, roots number $(\mathbf{C})$, shoots number (D), shoots fresh weight $(\mathbf{E})$, and roots dry weight $(\mathbf{F})$ of sugarcane accessions at 60 days in vitro cultivation in different saline concentrations $(0 ; 50 ; 100 ; 150 ; 200 \mathrm{mM} \mathrm{NaCl})$. $\bullet$ S. robustum (Q45251); \ Saccharum spp. (Q45416); - S. officinarum (Q44830).

There was a negative linear response to the roots number for S. officinarum (Q44830) and quadratic for S. robustum (Q45251) and Saccharum spp. (Q45416). The smallest root induction occurred in the presence of $177.83 \mathrm{mM} \mathrm{NaCl}$ in Saccharum spp. and $175 \mathrm{mM}$ in $S$. robustum, with estimated averages of 2.6 and 4.19 roots per plant, respectively. S. robustum (Q45251) stood out for its greater roots production (14.0) in absence of salt. There were no differences among the accessions in the 50 to $150 \mathrm{mM} \mathrm{NaCl}$ concentrations, only in the more severe concentration, in which $S$. officinarum (Q44830) produced more roots. Munns et al. (2002) states that the roots reduction in saline stress is an exclusive result of changes in water relations of the cell. 
Considering the roots length, in the three accessions there was linear reduction as the medium became increasingly more saline (Figure 1B). Excess salts in root zone of plants may result in reduction in the length and number of roots, exerting adverse effects on the growth and plant development (RHOADES et al., 2000). To the authors, the hypothesis that better explains this fact is that the detrimental effect of high salt levels in external environments to the roots decreases the plant's ability to absorb water and nutrients, thus reducing the amount of nutrients available to be translocated to other organs, leading to lower growth and plant development.

The presence of $\mathrm{NaCl}$ in the cultivation medium promoted different responses on the shoots production in the studied accessions. In $S$. officinarum (Q44830), the lowest shoots production (1.53) was achieved in $104.25 \mathrm{mM} \mathrm{NaCl}$. For $S$. robustum (Q45251) this value was $110.75 \mathrm{mM}$ with an average 3.16 shoots. On the other hand, the shoots reduction was linear in Saccharum spp. (Q45416) (Figure 1 D). In salt absence, Saccharum robustum (Q45251) presents the highest average (5.86). In the two most severe saline treatments, there was no statistical difference among the three accessions. Santos et al. (2009) highlight that the salinity effects on the plants growth rate are more pronounced in younger tissue, such as shoots and buds, because the osmotic potential increase in saline medium affects the water and nutrients absorption in cultivation medium, undermining growing points and cell expansion.

For the shoots dry weigh and roots fresh weight, a significant effect was observed only in the accession; for roots dry weight, only saline treatment effect; and for shoots fresh weight, accession and saline treatment effect.

In general, there was a reduction of biomass as the saline treatment became increasingly more concentrated (Figure 1E, Figure 2). For the root, quadratic behavior was observed to describe the results, with smaller biomass at $150 \mathrm{mM} \mathrm{NaCl}$. Considering the accessions, Saccharum robustum presented greater biomass at 60 days (Table 2).
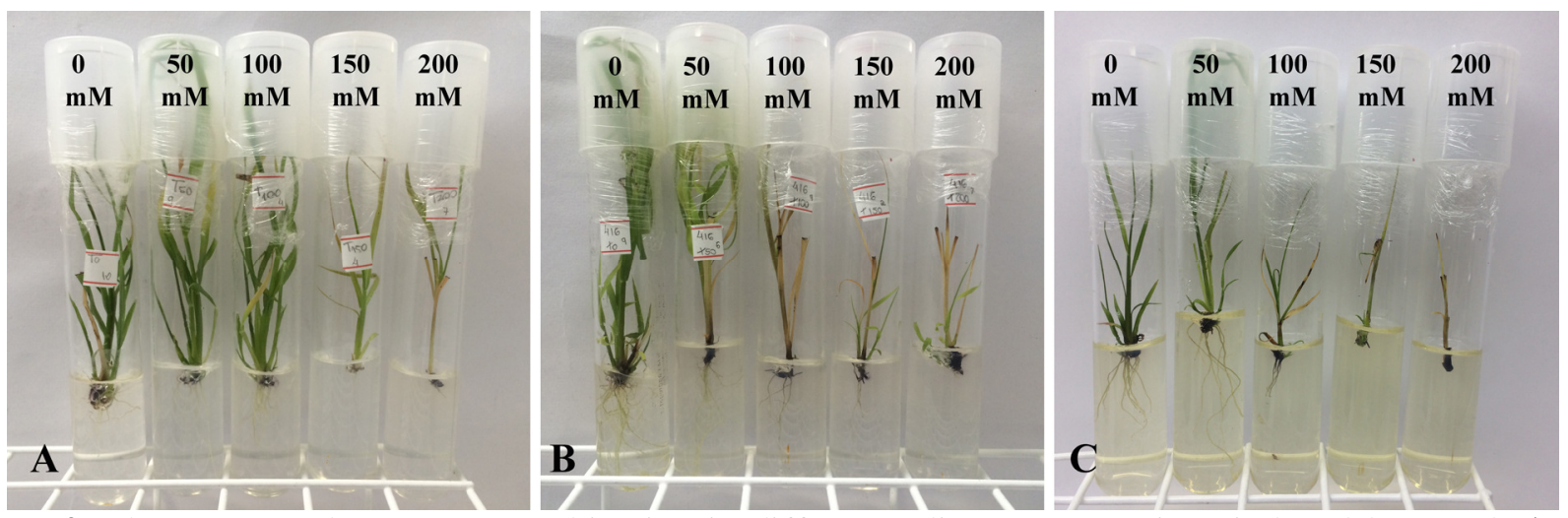

Figure 2. Shoots at 40 days in vitro cultivation in different saline concentrations induced by $\mathrm{NaCl}$. A $-S$. robustum (Q45251), B - Saccharum spp. (Q45416), C - S. officinarum (Q44830).

Table 2. Biomass of sugarcane accessions (mean \pm standard error of the mean) at 60 days in vitro cultivation subjected to in vitro saline stress. FW - fresh weight; DW - dry weight

\begin{tabular}{lcccc}
\hline \multicolumn{1}{c}{ Accessions } & FW shoots & DW shoots & FW roots & DW roots \\
\hline S. robustum (Q45251) & $0.71 \pm 0.07 \mathrm{a}^{1}$ & $0.11 \pm 0.03 \mathrm{a}$ & $0.67 \pm 0.09 \mathrm{a}$ & $0.004 \pm 0.00 \mathrm{a}$ \\
Saccharum spp. (Q45416) & $0.25 \pm 0.06 \mathrm{~b}$ & $0.04 \pm 0.01 \mathrm{~b}$ & $0.06 \pm 0.02 \mathrm{~b}$ & $0.0045 \pm 0.00 \mathrm{a}$ \\
S. officinarum (Q44830) & $0.19 \pm 0.04 \mathrm{~b}$ & $0.03 \pm 0.01 \mathrm{~b}$ & $0.04 \pm 0.01 \mathrm{~b}$ & $0.004 \pm 0.00 \mathrm{a}$ \\
\hline CV $(\%)$ & 9.63 & 5.21 & 11.64 & 0.26 \\
\hline
\end{tabular}

${ }^{1}$ Means followed by the same letter in the column do not differ by Tukey test at $0.05 \%$.

Studies by Patade et al. (2011) have shown that sugarcane plants (Saccharum officinarum L. cv. Co 86032) cultivated with $150 \mathrm{mM} \mathrm{NaCl}$ during 15 days showed a significant reduction in dry weight, area and length of leaves, compared with the control, due to the accumulation of toxic saline ions, which changed the growth rate, possibly to aid the plant in reducing water use, and, therefore, a mechanism to avoid stress.

The variables shoots fresh weight, shoots dry weight, roots fresh weight, and roots dry weight were significantly influenced by salt levels in a 
study by Simões et al. (2016). There were linear reductions in salinity levels, reaching relative reductions of $48,29,35$, and $77 \%$, respectively, to the $8 \mathrm{dS} \mathrm{m}^{-1}(80 \mathrm{mM})$ treatment when compared with the control, thus showing greater sensitivity of roots dry weight to variations of salinity and less sensitivity of shoots dry weight, corroborating the result of this study.

In addition, saline stress also significantly reduced the shoots growth and roots length in varieties (CoC671 and $\mathrm{CoC} 24)$ of Saccharum officinarum with the increasing levels of salinity, especially at $200 \mathrm{mM} \mathrm{NaCl}$ (ANITHA et al., 2015), demonstrating that the reduction caused by stress is due to the inhibited growth by the apical part of the plant, as well as by the endogenous hormone imbalance (YOUNIS et al., 2010).

In sugarcane in vitro-cultured (cv. C-105173) implemented in bioreactors, $\mathrm{NaCl} 200 \mathrm{mM}$ decreased shoot multiplication rate in $90,4 \%$ of that obtained in the control treatment without $\mathrm{NaCl}$, while fresh weight decreased 83,9\% (GOMÉZ et al. 2017). Reduction of fresh weight, shoots length, roots length, and leaf area were also reported by Cha-Um and Kirdmanee (2009) in sugarcane ( $S$. officinarum) under saline stress (-1.2 Mpa).

\section{Effect of salinity on Proline content}

There was a significant effect $(p<0.5)$ in the triple interaction among factors time, accession, and saline stress on proline content.

In S. robustum (Q45251) and Saccharum spp. (Q45416) there was a significant linear increase in proline content as the medium became more saline at 20, 40 and 60 days. In S. officinarum (Q44830), there was a linear response with a significant increase at 20 days; quadratic at 40 days, with higher proline production $\left(15.03 \mu \mathrm{mol} \mathrm{g}{ }^{-1} \mathrm{FW}\right)$ in $98 \mathrm{mM} \mathrm{NaCl}$; and at 60 days this production was not significant (Figure3).

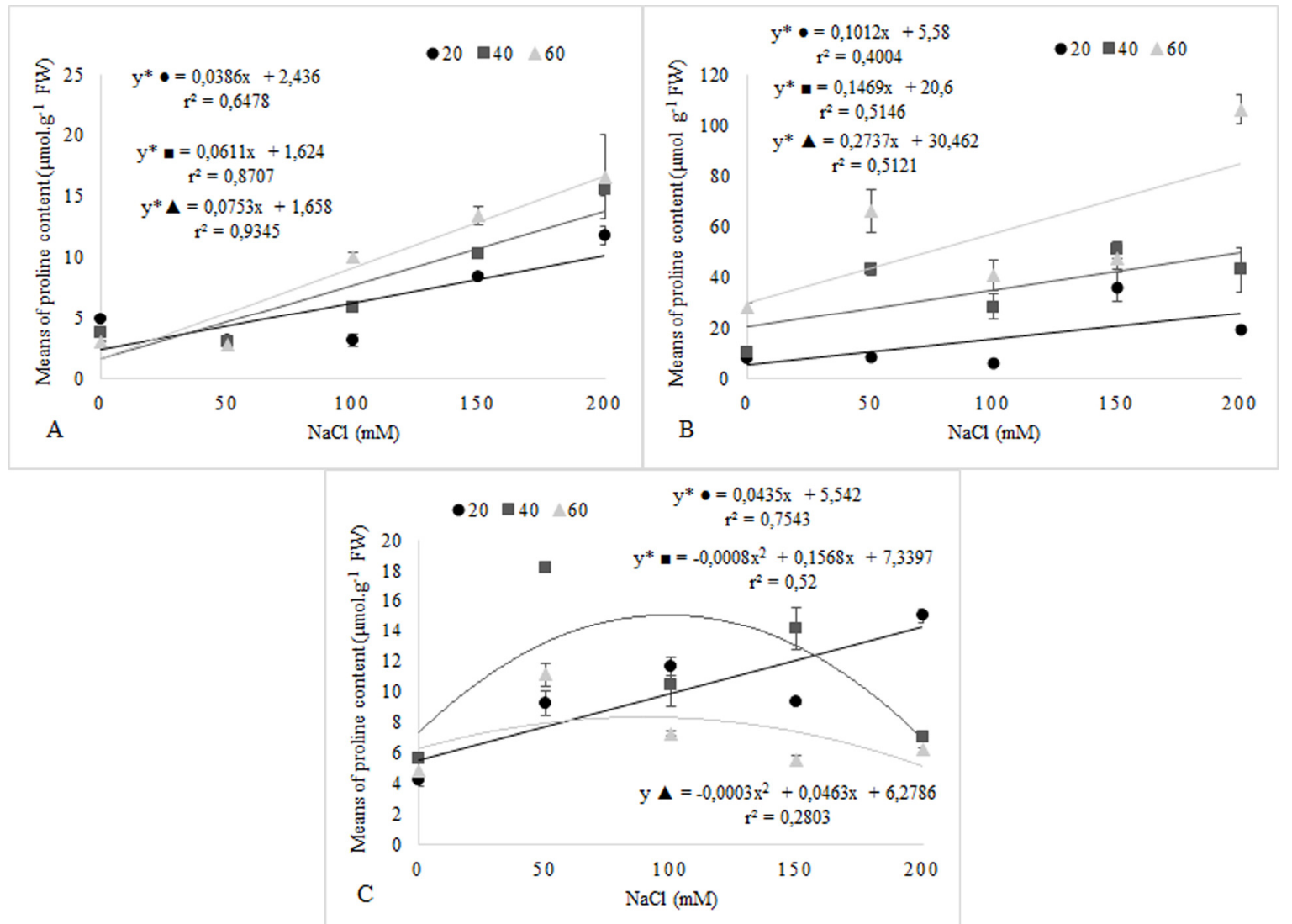

Figure 3. Effect salinity on proline content in A - S. robustum (Q45251), B - Saccharum spp.(Q45416), C - S. officinarum (Q44830) at 20,40, 60 days in vitro cultivation in different saline concentrations $(0 ; 50$; $100 ; 150 ; 200 \mathrm{mM}$ of $\mathrm{NaCl})$.

Greater averages were reached in the accession Q45416 (Saccharum spp.) at 60 days of cultivation in saline medium (Table 3). This accession also stood out in other evaluation times, which shows natural osmoregulation attempts, since the solutes accumulation, such as proline, enables the plant to develop reactions that allow for the continuity of physiological processes (MARIJUAN; $\mathrm{BOSCH}, 2013)$. This accumulation enabled the survival and maintenance of plant growth, although 
smaller, when compared with the treatment without $\mathrm{NaCl}$.

Considering the accession Q45251 (Saccharum robustum), there was no statistical difference among the proline levels in the assessed times of all treatments, indicating that the contents of this amino acid has not increased in function of stress time, proving its tolerance to the salt levels studied.

In S. officinarum there was no difference in amino acid production in the three assessed times for 0,100 and $150 \mathrm{mM} \mathrm{NaCl}$. In $50 \mathrm{mM} \mathrm{NaCl}$, there was higher production at 40 days, and at $200 \mathrm{mM}$ $\mathrm{NaCl}$, higher production at 20 days.

Table 3. Free proline content $\left(\mu \mathrm{mol} \mathrm{g}{ }^{-1} \mathrm{FW}\right)$ on sugarcane accessions (mean \pm standard error of the mean), at 20, 40, and 60 days of in vitro cultivation under saline stress.

\begin{tabular}{|c|c|c|c|}
\hline \multirow{2}{*}{ Accessions } & \multicolumn{3}{|c|}{ Days } \\
\hline & 20 & 40 & 60 \\
\hline & \multicolumn{3}{|c|}{$0 \mathrm{mM} \mathrm{NaCl}$} \\
\hline S. robustum (Q45251) & $4.87 \pm 0.00 \mathrm{aA}^{1}$ & $3.85 \pm 0.30 \mathrm{aA}$ & $3.10 \pm 0.03 \mathrm{aB}$ \\
\hline Saccharum spp. (Q45416) & $7.89 \pm 0.21 \mathrm{bA}$ & $10.22 \pm 0.83 \mathrm{bA}$ & $28.39 \pm 1.72 \mathrm{aA}$ \\
\hline \multirow[t]{2}{*}{ S. officinarum (Q44830) } & $4.19 \pm 0.32 \mathrm{aA}$ & $5.61 \pm 0.07 \mathrm{aA}$ & $4.87 \pm 0.70 \mathrm{aB}$ \\
\hline & \multicolumn{3}{|c|}{$50 \mathrm{mM} \mathrm{NaCl}$} \\
\hline S. robustum (Q45251) & $3.14 \pm 0.14 \mathrm{aA}$ & $3.09 \pm 0.22 \mathrm{aC}$ & $2.79 \pm 0.22 \mathrm{aB}$ \\
\hline Saccharum spp. (Q45416) & $8.64 \pm 0.29 \mathrm{cA}$ & $43.43 \pm 2.31 \mathrm{bA}$ & $66.04 \pm 8.43 \mathrm{aA}$ \\
\hline \multirow[t]{2}{*}{ S. officinarum (Q44830) } & $9.28 \pm 0.80 \mathrm{bA}$ & $18.20 \pm 0.36 \mathrm{aB}$ & $11.10 \pm 0.77 \mathrm{abB}$ \\
\hline & \multicolumn{3}{|c|}{$100 \mathrm{mM} \mathrm{NaCl}$} \\
\hline S. robustum (Q45251) & $3.15 \pm 0.50 \mathrm{aA}$ & $5.91 \pm 0.07 \mathrm{aB}$ & $10.02 \pm 0.38 \mathrm{aB}$ \\
\hline Saccharum spp. (Q45416) & $6.28 \pm 0.72 \mathrm{cA}$ & $28.63 \pm 5.37 \mathrm{bA}$ & $41.22 \pm 5.95 \mathrm{aA}$ \\
\hline \multirow[t]{2}{*}{ S. officinarum (Q44830) } & $11.63 \pm 0.62 \mathrm{aA}$ & $10.42 \pm 1.40 \mathrm{aB}$ & $7.28 \pm 0.11 \mathrm{aB}$ \\
\hline & \multicolumn{3}{|c|}{$150 \mathrm{mM} \mathrm{NaCl}$} \\
\hline S. robustum (Q45251) & $8.48 \pm 0.16 \mathrm{aB}$ & $10.30 \pm 0.10 \mathrm{aB}$ & $13.44 \pm 0.75 \mathrm{aB}$ \\
\hline Saccharum spp. (Q45416) & $36.35 \pm 5.59 \mathrm{bA}$ & $51.02 \pm 3.32 \mathrm{aA}$ & $47.33 \pm 3.99 \mathrm{aA}$ \\
\hline \multirow[t]{2}{*}{ S. officinarum (Q44830) } & $9.33 \pm 0.14 \mathrm{aB}$ & $14.16 \pm 1.40 \mathrm{aB}$ & $5.57 \pm 0.28 \mathrm{aB}$ \\
\hline & \multicolumn{3}{|c|}{$200 \mathrm{mM} \mathrm{NaCl}$} \\
\hline S. robustum (Q45251) & $11.86 \pm 0.74 \mathrm{aA}$ & $15.52 \pm 0.41 \mathrm{aB}$ & $16.61 \pm 3.42 \mathrm{aB}$ \\
\hline Saccharum spp. (Q45416) & $19.23 \pm 1.2 \mathrm{cA}$ & $43.15 \pm 8.94 \mathrm{bA}$ & $106.16 \pm 5.6 \mathrm{aA}$ \\
\hline S. officinarum (Q44830) & $15.05 \pm 0.46 \mathrm{aA}$ & $7.08 \pm 0.30 \mathrm{abB}$ & $6.19 \pm 0.16 \mathrm{bC}$ \\
\hline
\end{tabular}

${ }^{1}$ Means followed by the same lowercase in the line and capital letters in the column do not differ by Tukey test at $0.05 \%$.

In response to stress, plants can synthesize compatible solutes in the cytosol. These low molecular weight compounds, which intervene little in the usual biochemical reactions of the plant, act on osmotic adjustment, protection of cell macromolecules, storage of nutrients, maintenance of cellular pH (ASHRAF; HARRIS, 2004), and from their osmoprotective function, protect the plants from toxic bioproducts produced as secondary effects during ionic stress (TAIZ; ZEIGER, 2009).

The amino-acid proline is the most studied solute due to its response sensitivity to stress conditions, such as extreme temperature, drought, salinity, and heavy metals, with possibility of increasing by up to 100 times in comparison with normal plants, thus providing an important parameter for the selection of resistant plants (VERBRUGGEN; HERMANS, 2008). In this research, proline levels increased up to five times in $\mathrm{NCl}$ treated plants relative to control.

Munns and Tester (2008) state that proline has two functional roles: high concentrations indicate osmotic adjustment and low concentrations indicate protective effect. In the osmotic adjustment, the osmolytes facilitate the retention of water in the cytoplasm and allow $\mathrm{Na}^{+}$sequestration for the vacuole or apoplast (ASHRAF; HARRIS, 2004).

On sugarcane, there are many reports about the accumulation proline in callus culture, seedlings, and adult plants, when exposed to the increase of saline stress concentration

(CHA-UM; 
KIRDMANEE, 2009; ERRABI et al., 2007; GANDONOU et al., 2006; PATADE et al., 2008). Gandonou et al. (2005) studying varieties of sugarcane under conditions of in vitro saline stress, observed that both the sensitive variety CP65-357 and the resistant variety NCo310 behaved similarly, accumulating greater amounts of proline in the more severe saline treatments $(102 \mathrm{mM})$. Granja et al (2018) evaluating the response of two commercial varieties of sugarcane (RB931011 and RB872552), exposed to in vitro salt stress by $\mathrm{NaCl}(56 \mathrm{mM}$ and $112 \mathrm{mM}$ ), concluded that the proline content increased only in plants submitted to treatment with $112 \mathrm{mM}$ of $\mathrm{NaCl}$, granting to the sugarcane varieties a greater protection against salt stress. These results reinforce the results found in the present study, in relation to the proline increase in plants submitted to increasing levels of $\mathrm{NaCl}$.

Similar results regarding the increase of the amino acid proline in function of the increase of stress were also reported for varieties of Saccharum officinarum subjected to other stresses such as water induced by PEG (ABBAS et al., 2014), and UV radiation (AVINASH et al., 2012).

\section{Effect of salinity on total chlorophyll content}

At 20 days of in vitro cultivation, the chlorophyll content of Saccharum spp. remained stable with the increase salt stress, that is, there was no significant increase, demonstrating that, at that time, salinity did not significantly influence the metabolic processes of this accession. In $\mathrm{S}$. robustum (Q45251), the lowest chlorophyll production $\left(0.92 \mathrm{mg} . \mathrm{g}^{-1} \mathrm{FW}\right)$ occurred in $115 \mathrm{mM}$ $\mathrm{NaCl}$ at 20 days. I S. officinarum (Q44830), the decrease in production was linear for this time of evaluation. At 40 and 60 days of in vitro cultivation, the behavior of the three accessions was similar, with a significant linear decrease in photosynthetic pigment production with the increased salinity (Figure 4).
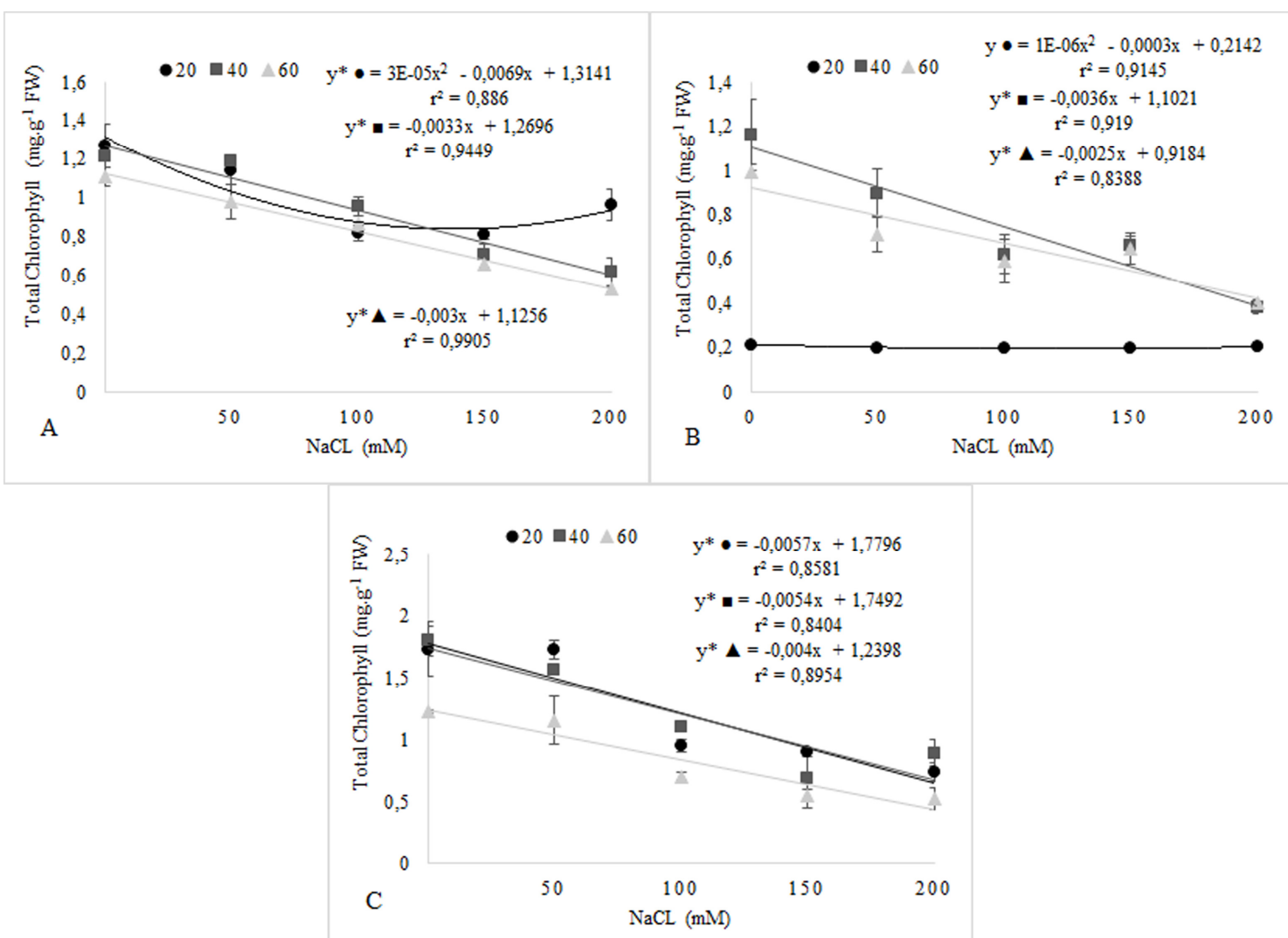

Figure 4. Effect of salinity on the chlorophyll content on A - S. robustum (Q45251), B - Saccharum spp.(Q45416), C - S. officinarum (Q44830) at 20, 40, 60 days in vitro cultivation in different saline concentrations $(0 ; 50 ; 100 ; 150 ; 200 \mathrm{mM}$ of $\mathrm{NaCl})$.

Regarding S. robustum, a statistical difference was observed concerning the time of in vitro cultivation only at $200 \mathrm{mM}$ of salt, in which the control treatment showed higher total chlorophyll content (Table 4). As for S. officinarum, it ptresented a difference only at 60 days in all studied treatments, and for Saccharum spp., the behavior varied with time, but overall, there was no 
difference between the assessments at 40 and 60 days.

Comparing the three accessions, $S$. robustum and $S$. officinarum presented a very similar behavior, with the latter presenting better averages regarding the smallest degradation of the photosynthetic pigment, showing itself as a more effective protection against saline stress. Saccharum spp. presented lower averages.

Table 4. Total chlorophyll content (mg. $\mathrm{g}^{-1} \mathrm{FW}$ ) on sugarcane accessions (mean \pm standard error of the mean), at 20,40 , and 60 days of in vitro cultivation under saline stress.

\begin{tabular}{|c|c|c|c|}
\hline \multirow{2}{*}{ Accessions } & \multicolumn{3}{|c|}{ Days } \\
\hline & 20 & 40 & 60 \\
\hline & \multicolumn{3}{|c|}{$0 \mathrm{mM} \mathrm{NaCl}$} \\
\hline S. robustum (Q45251) & $1.27 \pm 0.11 \mathrm{aB}^{1}$ & $1.22 \pm 0.05 \mathrm{aB}$ & $1.11 \pm 0.05 \mathrm{aA}$ \\
\hline Saccharum spp. (Q45416) & $0.21 \pm 0.00 \mathrm{cC}$ & $1.61 \pm 0.16 \mathrm{aA}$ & $0.99 \pm 0.03 \mathrm{bA}$ \\
\hline \multirow[t]{2}{*}{ S. officinarum (Q44830) } & $1.74 \pm 0.22 \mathrm{aA}$ & $1.80 \pm 0.12 \mathrm{aA}$ & $1.23 \pm 0.01 \mathrm{bA}$ \\
\hline & \multicolumn{3}{|c|}{$50 \mathrm{mM} \mathrm{NaCl}$} \\
\hline S. robustum (Q45251) & $1.14 \pm 0.07 \mathrm{aB}$ & $1.19 \pm 0.02 \mathrm{aB}$ & $0.98 \pm 0.09 \mathrm{aAB}$ \\
\hline Saccharum spp. (Q45416) & $0.20 \pm 0.00 \mathrm{bC}$ & $0.89 \pm 0.11 \mathrm{aC}$ & $0.71 \pm 0.08 \mathrm{aB}$ \\
\hline \multirow[t]{2}{*}{ S. officinarum (Q44830) } & $1.73 \pm 0.08 \mathrm{aA}$ & $1.57 \pm 0.02 \mathrm{aA}$ & $1.16 \pm 0.20 \mathrm{bA}$ \\
\hline & \multicolumn{3}{|c|}{$100 \mathrm{mM} \mathrm{NaCl}$} \\
\hline S. robustum (Q45251) & $0.82 \pm 0.04 \mathrm{aA}$ & $0.96 \pm 0.05 \mathrm{aA}$ & $0.87 \pm 0.01 \mathrm{aA}$ \\
\hline Saccharum spp. (Q45416) & $0.20 \pm 0.00 \mathrm{bB}$ & $0.62 \pm 0.09 \mathrm{aB}$ & $0.59 \pm 0.10 \mathrm{aB}$ \\
\hline \multirow{2}{*}{ S. officinarum (Q44830) } & $0.96 \pm 0.05 \mathrm{abA}$ & $1.10 \pm 0.02 \mathrm{aA}$ & $0.71 \pm 0.03 \mathrm{bAB}$ \\
\hline & \multicolumn{3}{|c|}{$150 \mathrm{mM} \mathrm{NaCl}$} \\
\hline S. robustum (Q45251) & $0.81 \pm 0.03 \mathrm{aA}$ & $0.70 \pm 0.06 \mathrm{aA}$ & $0.66 \pm 0.03 \mathrm{aA}$ \\
\hline Saccharum spp. (Q45416) & $0.19 \pm 0.00 \mathrm{bB}$ & $0.66 \pm 0.04 \mathrm{aA}$ & $0.65 \pm 0.07 \mathrm{aA}$ \\
\hline \multirow[t]{2}{*}{ S. officinarum (Q44830) } & $0.90 \pm 0.03 \mathrm{aA}$ & $0.69 \pm 0.23 \mathrm{abA}$ & $0.56 \pm 0.05 \mathrm{bA}$ \\
\hline & \multicolumn{3}{|c|}{$200 \mathrm{mM} \mathrm{NaCl}$} \\
\hline S. robustum (Q45251) & $0.96 \pm 0.08 \mathrm{aA}$ & $0.62 \pm 0.07 \mathrm{bB}$ & $0.53 \pm 0.01 \mathrm{bA}$ \\
\hline Saccharum spp. (Q45416) & $0.20 \pm 0.00 \mathrm{aB}$ & $0.38 \pm 0.03 \mathrm{aB}$ & $0.40 \pm 0.00 \mathrm{aA}$ \\
\hline S. officinarum (Q44830) & $0.74 \pm 0.08 \mathrm{abA}$ & $0.90 \pm 0.11 \mathrm{aA}$ & $0.53 \pm 0.09 \mathrm{bA}$ \\
\hline
\end{tabular}

${ }^{1}$ Means followed by the same lowercase in the line and capital letters in the column do not differ by Tukey test at $0.05 \%$.

Similar results were observed in three sugarcane accessions at $200 \mathrm{mM}$ of salt during seven days, in which chlorophyll was degraded (POONSAWAT et al., 2015). The total chlorophyll level in CoM-265, salt tolerant, cultivated under 7-8 $\mathrm{dS} \mathrm{m}^{-1}$ (70 to $80 \mathrm{mM}$ ) during five days decreased only $8.84 \%$ compared with the $30.50 \%$ decline in CoC-671, salt-sensitive, which means to say that the smaller pigment degradation favored better photosynthetic activities in saline conditions (SATBHAI; NAIK, 2014). In addition, Pagariya et al. (2012) also reported that chlorophyll degradation depends on the time of exposure to salt, showing that sugarcane cultivar Co62175 was more sensitive in the long term salt treatment $(\mathrm{NaCl}$ at $2 \%$ for 30 days) than in the short term.
A linear total chlorophyll content reduction at $45 \%$ and $20 \%$ in CoC 671 (sensitive) and $\mathrm{CoC} 24$ (tolerant), respectively, with an increase in salinity level $(200 \mathrm{mM})$ was reported by Anitha et al. (2015), demonstrating that the chlorophyll reduction due to stress is related to increased free radicals production in the cell. These free radicals cause peroxidation, disintegration, and chlorophyll content reduction in plants under stressful conditions. Other similar results with sugarcane were also found by Cha-um and Kirdmanee (2009) in Saccharum officinarum and by Christy et al. (2013) in other two tolerant and resistant cultivars.

\section{Effect of salinity on leaf anatomy}

Regarding leaf anatomy, sugarcane presents cuticle with uni-stratified tissue with thin walls cells 
in the epidermis on both sides. The cuticle plays an important role to minimize water loss and increase the plants resistance to biotic changes by signaling possible stresses (WANG et al., 2011). In the three studied accessions, despite cuticle changes, no degradation occurred.

Bulliform cells are present in fan-shaped in different sizes, only on the adaxial face of the epidermis and are associated with colorless cells. They are motor cells, highly vacuolated, and under conditions of salinity they lose turgor pressure, causing the winding of the leaves in the accession Q45416 (Saccharum spp.). In the other two accessions, these cells remained turgid even with the increase of the concentration of salt in the medium (Figure 5).

The mesophile, composed by palisade and spongy parenchyma, was not damaged in all studied accessions.

The vascular beams are surrounded by an additional layer of cells particular to plants of $\mathrm{C} 4$ metabolism, the parenchymatic vascular sheath. $\mathrm{CO}_{2}$ is captured in these cells and by increasing its concentration by up to ten times, it ends up avoiding water loss (TAIZ; ZEIGER, 2009).

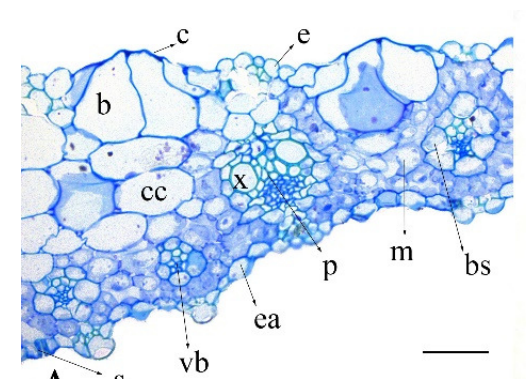

A s
B

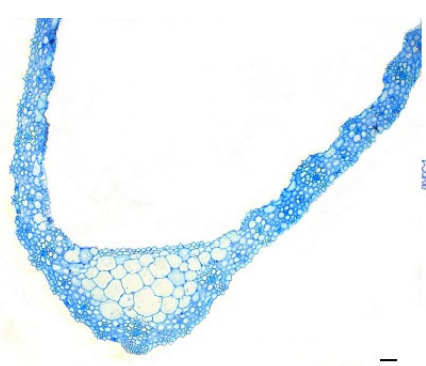

C

Figure 5. Cross-sectional sections of sugarcane leaves submitted to $200 \mathrm{~mm}$ of $\mathrm{NaCl}$ at 60 days of cultivation in vitro. A - S. robustum (Q45251), B - Saccharum spp. (Q45416), C - S. officinarum (Q44830). Structures: b - bulliform cells, bs - bundle sheath cells, c - cuticle, cc - colorless cells, e - adaxial surface epidermis, ea - abaxial surface epidermis, $\mathbf{m}$ - mesophyll, $\mathbf{p}$ - phloem, $\mathbf{s}$ - stomata, vb vascular bundles, $\mathbf{x}-$ xylem. Scale bar $50 \mu \mathrm{m}$.

\section{CONCLUSIONS}

The in vitro growth of accessions Saccharum robustum, Saccharum spp. and Saccharum officinarum are affected by salinity induced by $\mathrm{NaCl}$.

The accumulation of proline and decrease in total chlorophyll content are intensified in Saccharum spp.

The decrease of turgidity caused the decrease of bulliform cells and winding of the leaves in Saccharum spp.

\section{ACKNOWLEDGMENT}

This study was financed in part by the Conselho Nacional de Desenvolvimento Científico e Tecnológico - Brasil (CNPq), the Fundação de Apoio à Pesquisa e a Inovação Tecnológica do Estado de Sergipe (Fapitec/SE) - Brasil, the Coordenação de Aperfeiçoamento de Pessoal de Nível Superior - Brasil (CAPES - Finance Code 001), and the Financiadora de Estudos e Projetos Brasil (FINEP).

RESUMO: Os estresses abióticos em plantas têm despertado grande interesse da pesquisa, que tem buscado incessantemente por cultivares mais produtivas sob condições desfavoráveis de cultivo. A deficiência hídrica e a salinidade do solo são os mais estudados, em razão de seu forte impacto sobre o crescimento e a produtividade das plantas. O objetivo deste estudo foi avaliar acessos de diferentes espécies de cana-de-açúcar (Saccharum robustum, Saccharum spp., S. officinarum), quanto a tolerância à salinidade in vitro, a partir de alterações nos parâmetros fisiológicos, anatômicos, bioquímicos e biométricos, para auxiliar em futuros programas de melhoramento. Para tanto foram utilizadas brotações, cultivadas em meio Murashige e Skoog, suplementado com 2\% de sacarose e 4 g.L-1 de Phytagel, na presença de cinco concentrações 0, 50,100,150, $200 \mathrm{mM}$ de NaCl. Comprimento das brotações e da raiz, número de brotações e de raízes, peso fresco, peso seco, teor de prolina nas folhas, conteúdo de clorofila total e alterações morfológicas dos tecidos foliares foram analisados. O crescimento in vitro dos acessos Saccharum robustum, Saccharum spp. e Saccharum officinarum é afetado pela salinidade induzida por $\mathrm{NaCl}$. O acúmulo de prolina e decréscimo de clorofila é intensificado em Saccharum spp., além de mudança na anatomia de células, caracterizando-se como mais sensível ao sal. 
PALAVRAS-CHAVE: Clorofila. Histologia. Prolina. Saccharum officinarum. Saccharum robustum. Saccharum spp.

\section{REFERENCES}

ABBAS, S. R.; AHMAD, S. D.; SABIR, S. M.; SHAH, A. H. Detection of drought tolerant sugarcane genotypes (Saccharum officinarum) using lipid peroxidation, antioxidante activity, glycine-betaine and proline contentes. Journal of Soil Science and Plant Nutrition, v. 14, n. 1, p. 233-243, 2014.

AKHTAR, S.; WAHID, A.; RASUL, E. Emergence, growth and nutrient composition of sugarcane sprouts under NaCl salinity. Biologia Plantarum, v. 46, n. 1, p. 113-116, 2003.

https://doi.org/10.1023/A:1022326604192

ANDRADE, S. R. Princípios da cultura de tecidos vegetais. Planaltina, Documentos/EMBRAPA CERRADOS, 2002. 58p

ANITHA, R.; MARY, P. C. N.; SAVERY, M. A. J. R.; SRITHARAN, N.; PURUSHOTHAMAN, R. S. Differential responses of sugarcane (Saccharum officinarum L.) genotypes under salt stress condition. Plant Archives, v. 15, n. 2, p. 1055-1060, 2015.

ARNON, D. I. Copper enzymes in isolated chloroplasts: polyphenoloxydase in Beta vulgaris. Plant Physiology, v. 4, n. 1, p. 1-15, 1949. https://doi.org/10.1104/pp.24.1.1

ASHRAF, M.; HARRIS, P. J. C. Potential biochemical indicators of salinity tolerance in plants. Plant Science, v. 166, n. 1, p. 3-6, 2004. https://doi.org/10.1016/j.plantsci.2003.10.024

AVINASH, L.; PRASHANT, N.; BHAROSE, A. A. In vitro screening of sugarcane cultivar Co 86032 for salinity tolerance. Journal of Sugarcane Research, v. 2, n. 1, p. 25-31, 2012.

BATES L. S.; WALDREN R. P.; TEARE I. D. Rapid determination of free proline for water-stress studies. Plant Soil, v. 39, n. 1, p. 205-207, 1973. https://doi.org/10.1007/BF00018060

CASU, R. E.; DIMMOCK, C. M.; CHAPMAN, S. C.; GROF C. P. L., et al. Identification of differentially expressed transcripts from maturing stem of sugarcane by in silico analysis of stem expressed sequence tags and gene expression profiling. Plant Molecular Biology, v. 54, n. 4, p. 503-517, 2004.

https://doi.org/10.1023/B:PLAN.0000038255.96128.41

CASTILLO, E. G.; TUONG, T. P.; ISMAIL, A. M.; INUBUSHI, K. Response to salinity in rice: Comparative effects of osmotic and ionic stresses. Plant Production Science, v. 10, n. 2, p. 59-170, 2007.

https://doi.org/10.1626/pps.10.159

CHA-UM, S.; KIRDMANEE, C. Proline accumulation, photosynthetic abilities and growth characters of sugarcane (Saccharum officinarum L.) plantlets in response to iso-osmotic salt and water-deficit stress. Agricultural Science in China, v. 8, n. 1, p. 51-58, 2009. https://doi.org/10.1016/S1671-2927(09)60008-0

CHA-UM, S.; SUPAIBULWATANA, K.; KIRDMANEE, C. Glycinebetaine accumulation, physiological characterizations, and growth efficiency in salt tolerant and salt sensitive lines of indica rice (Oryza sativa $\mathrm{L}$. spp. indica) response to salt stress. Journal of Agronomy and Crop Science, v. 193, n. 3, p. 157-166, 2007. https://doi.org/10.1111/j.1439-037X.2007.00251.X

CHRISTY, P. M.; PREETHA, R. D.; VASANTHA, S.; DIVYA, D. Biochemical and molecular analysis of sugarcane genotypes response to salinity and drought. International journal of applied biology and pharmaceutical technology, v. 4, n. 1, p. 210-218, 2013. 
ERRABII, T.; GANDONOU, C. B.; ESSALMANI, H.; ABRINI, J.; et al. Effects os NaCl and mannitol induced stress on sugarcane (Saccharum sp.) callus cultures. Acta Physiologiae Plantarum, v. 29, p. 95-102, 2007. https://doi.org/10.1007/s11738-006-0006-1

FILIPPOU, P.; BOUCHAGIER, P.; SKOTTI, E.; FOTOPOULOS, V. Proline and reactive oxygen/nitrogen species metabolism is involved in the tolerant response of the invasive plant species Ailanthus altissima to drought and salinity. Environmental and Experimental Botany, v. 97, p. 1-10, 2014. https://doi.org/10.1016/j.envexpbot.2013.09.010

GANDONOU, C. B.; ERRABI, T.; ABRINI, J.; IDAOMAR, M.; SENHAJI, N. S. Selection of callus cultures of sugarcane (Saccharum sp.) tolerant to $\mathrm{NaCl}$ and their response to salt stress. Plant Cell Tissue and Organ Culture, v. 87, n. 1, p. 9-16, 2006.

GANDONOU, C. H. ; ABRINI, J. ; IDAOMAR, M. ; SKALI-SENHAJI, N. Effects of NaCl on growth and ion and proline accumulation in sugarcane (Saccharum sp.) callus culture. Belgian Journal of Botany, v. 138, n. 2, p. 173-180, 2005. ttps://doi.org/10.1007/s11240-006-9113-3

GOMÉZ, D.; HERNÁNDEZ, L.; VALLE, B; MARTÍNEZ, J.; CID, M.; ESCALONA, M.; HERNÁNDEZ, M.; YABOR, L.; BEEMSTER, G. T. S.; TEBBE, C. C.; PAPENBROCK, J.; LORENZO, J. C. Salinity induces specific metabolic changes in sugarcane shoot explants in temporary immersion bioreactors. Journal of Applied Botany and Food Quality, v. 90, p. 354-358, 2017.

GORDIN, C. R. B.; MARQUES, R. F.; MASSETO, T. E.; SOUZA, L. C. F. de. Estresse salino na germinação de sementes e desenvolvimento de plântulas de niger (Guizotia abyssinica (L.f.) Cass.). Acta Botanica Brasilica, v. 26, n. 4, p. 966-972, 2012. https://doi.org/10.1590/S0102-33062012000400026

GRANJA, M. M. C.; MEDEIROS, M. J. L.; SILVA, M. M. A.; CAMARA, T. R.; WILLADINO, L.; ULISSES, C. Response to in vitro salt stress in sugarcane is conditioned by concentration and condition of exposure to $\mathrm{NaCl}$. Acta Biologica Colombiana, v. 23, n. 1, p. 30-38, 2018.

https://doi.org/10.15446/abc.v23n1.63513

HU, Y.; BURUCS, Z.; VON TUCHER, S.; SCHMIDHALTER, U. Short term effects of drought and salinity on mineral nutrient distribution along growing leaves of maize seedlings. Environmental and Experimental Botany, v. 60, n. 2, p. 268-275, 2007. https://doi.org/10.1016/j.envexpbot.2006.11.003

MARIJUAN, M. P.; BOSCH, S. M. Ecophysiology of invasive plants: osmotic adjustment and antioxidants. Trends in Plant Science, v. 18, n. 12, p. 660-666, 2013.

https://doi.org/10.1016/j.tplants.2013.08.006

MUDGAL, V.; MADAAN, N.; MUDGAL, A. Biochemical mechanisms of salt tolerance in plants: A review. International Journal of Botany, v. 6, p. 136-143, 2010. https://doi.org/10.3923/ijb.2010.136.143

MUNNS, R.; JAMES, R. A.; LAUCHLI, A. Approaches to increasing the salt tolerance of wheat and other cereals. Journal of Experimental Botany, v. 57, n. 5, p. 1025-1043, 2006. https://doi.org/10.1093/jxb/erj100

MUNNS, R.; TESTER, M. Mechanisms of salinity tolerance. Annual Review of Plant Biology, v. 59, p. 65181, 2008.https://doi.org/10.1146/annurev.arplant.59.032607.092911

MUNNS, R.; HUSAIN, S. RIVELLI, A. R.; RICHARD, A. J.; CONDON, A. G.; MEGAN, P. L.; EVANS, S. L.; SCHACHTMAN, D. P.; HARE, R. A. Avenues for increasing salt tolerance of crops, and the role of physiologically based selection traits. Plant and Soil, v. 247, n. 1, p. 93-105, 2002.

https://doi.org/10.1023/A:1021119414799

MURASHIGE, T.; SKOOG, F. A. A revised medium for rapid growth and bioassays with tobacco tissue cultures. Physiologia Plantarum, v. 15, p. 473-497, 1962. https://doi.org/10.1111/j.1399-3054.1962.tb08052.x 
NAWAZ, N.; HUSSAIN, K.; MAJEED, A.; KHAN, F.; AFGHAN, S.; ALI, K. Fatality of salt stress to plants: Morphological, physiological and biochemical aspects. African Journal Biotechnology, v. 9, n. 34, p. 54755480,2010

OLIVEIRA, L. A. R.; CARDOSO, M. N.; OLIVEIRA, A. C. A.; MACHADO, C. A.; CARDOSO, B. T.; SILVA, A.V.C.; LEDO, A.S. Effects of in vitro drought stress on growth, proline accumulation and antioxidant defense in sugarcane. Journal of Agricultural Science, v. 10, n. 5, p. 135-149, 2018a.

OLIVEIRA, L. A. R.; OLIVEIRA, A. C. A.; MACHADO, C. A.; CARDOSO, M. N.; SANTANA, F. V.; MIRANDA, I. C. D.; CASTRO, E. M.; SILVA, A. V. C.; LEDO, A. S. Induction, growth kinetics and morphohistological characterization of neem callus. Journal of Agricultural Science, v. 10, n. 6, p. 283-290, 2018 b.

PAGARIYA, M. C.; DEVARUMATH, R.; KAWAR, P. G. Biochemical characterization and identification of differentially expressed candidate genes in salt stressed sugarcane. Plant Science, v. 184, p. 1-13, 2012. https://doi.org/10.1016/j.plantsci.2011.12.002

PARIDA, A. K.; DAS, A. B. Salt tolerance and salinity effects on plants: a review. Ecotoxicology and Environmental Safety, v. 60, n. 3, p. 324-349, 2005. https://doi.org/10.1016/j.ecoenv.2004.06.010

PATADE, V. Y.; BHARGAVA, S.; SUPRASANNA, P. Salt and drought tolerance of sugarcane under isoosmotic salt and water stress: growth, osmolytes accumulation, and antioxidante defense. Journal of Plant Interactions, v.6, n.4, p.275-282, 2011. https://doi.org/10.1080/17429145.2011.557513

PATADE, V. Y.; BHARGAVA, S.; SUPRASANNA, P. Effects of $\mathrm{NaCl}$ and iso-osmotic PEG stress on growth, osmolytes accumulation and antioxidante defense in cultured sugarcane cells. Plant Cell Tissue and Organ Culture, v.108, n.2, p.279-286, 2012. https://doi.org/10.1007/s11240-011-0041-5

PATADE, V. Y.; SUPRASANNA, P.; BAPAT, V. A. Effects of salt stress in relation to osmotic adjustment on sugarcane (Sacharum officinarum L.) callus cultures. Plant Growth Regulation, v.55, p.169-173, 2008. https://doi.org/10.1007/s10725-008-9270-y

PLAUT, Z., MEINZER, F. C.; FEDERMAN, E. Leaf development, transpiration and ion uptake and distribution in sugarcane cultivars grown under salinity. Plant Soil, v.218, n.1-2, p.59-69, 2000. https://doi.org/10.1023/A:1014996229436

POONSAWAT, W.; THEERAWITAYA, C.; SUWAN, T.; MONGKOLSIRIWATANA, C.; et al. Regulation of some salt defense-related genes in relation to physiological and biochemical changes in three sugarcane genotypes subjected to salt stress. Protoplasma, v. 252, n. 1, p. 231-243, 2015. https://doi.org/10.1007/s00709014-0676-2

REDDY, I. N. B. L.; KIM, B. K.; YOON, I. S.; KIM, K. H.; KWON, T. R. Salt Tolerance in Rice: Focus on Mechanisms and Approaches. Rice Science, v. 24, n. 3, p. 123-144, 2017.

https://doi.org/10.1016/j.rsci.2016.09.004

RHOADES, J. D.; KANDIAH, A.; MASHALI, A. M. Uso de águas salinas para a produção agrícola. In: Gheyi HR, Sousa JR \& Queiroz JE (Eds.) Estudos FAO de irrigação e drenagem. Campina Grande, UFPB, 2000. p.40-48.

SANTOS, P. R.; RUIZ, H. A.; NEVES, J. C. L. ALMEIDA, E. F.; FREIRE, M. B. G.; FREIRE, F. J. Germinação, vigor e crescimento de cultivares de feijoeiro em soluções salinas. Revista Brasileira de Engenharia Agrícola e Ambiental, v. 13, p. 882-889, 2009. https://doi.org/10.1590/S141543662009000700010

SAS Institute Inc. Statistical Analysis System, SAS 9.4 Help and Documentation, Cary, NC: SAS Institute Inc., 2013. http://www.sas.com/en_us/software/sas9.html 
SATBHAI, R. D.; NAIK, R. M. Osmolytes accumulation, cell membrane integrity, and antioxidant enzymes in sugarcane varieties differing in salinity tolerance. Sugar Tech, v. 16, n. 1, p. 30-35, 2014.

https://doi.org/10.1007/s12355-013-0243-8

SIMÕES, W. L.; CALGARO, M.; COELHO, D. S.; SANTOS, D. B.; SOUZA, M. A. Growth of sugar cane varieties under salinity. Revista Ceres, v. 63, n. 2, p. 265-271, 2016. https://doi.org/10.1590/0034-

737X201663020019

TAIZ, L.; ZEIGER, E. Fisiologia vegetal. 4. ed. Porto Alegre: Artmed, 2009. 848p.

TEIXEIRA, J.; PEREIRA, S. High salinity and drought act on an organ-dependent manner on potato glutamine synthetase expression and accumulation. Environmental and Experimental Botany, v. 60, n. 1, p. 121-126, 2007. https://doi.org/10.1016/j.envexpbot.2006.09.003

WAHID, A.; GHAZANFAR, A. Possible involvement of some secondary metabolites in salt tolerance of sugar cane. Journal of Plant Physiology, v. 163, n. 7, p. 723-730, 2006. https://doi.org/10.1016/j.jplph.2005.07.007

WANG, Z.; XIONG, L.; LI, W.; ZHU, J.; ZHU, J. The plant cuticle is required for osmotic stress regulation of abscisic acid biosynthesis and osmotic stress tolerance in Arabidopsis. The Plant Cell May, v. 23, n. 5, p. 1971-1984, 2011.

WILLADINO, L. et al. Mechanisms of tolerance to salinity in banana: physiological, biochemical, and molecular aspects. Revista Brasileira de Fruticultura, v. 39, n. 2, p. 1-8, 2017. https://doi.org/10.1590/010029452017723

YOUNIS, M. E.; HASANEEN, M. N. A.; KAZAMEL, A. M. S. Exogenously applied ascorbic acid ameliorates detrimental effects of $\mathrm{NaCl}$ and mannitol stress in Vicia faba seedlings. Protoplasma, v. 239, n. 1, p. 39-48, 2010. https://doi.org/10.1007/s00709-009-0080-5

VASANTHA, S.; GOMATHI, R. Growth and development of sugarcane under salinity. Journal Sugarcane Research, v. 2, p. 1-10, 2012.

VERBRUGGEN, N.; HERMANS, C. Proline accumulation in plants: a review. Amino Acids, v. 35, n. 4, p. 753-759, 2008. https://doi.org/10.1007/s00726-008-0061-6 